\title{
ESTIMASI KARAKTERISTIK DURASI RUPTURE PADA GEMPA PEMBANGKIT TSUNAMI STUDI KASUS: GEMPA BUMI NIAS, 28 MARET 2005
}

\author{
Sayyidatul Khoiridah, Widya Utama \\ Jurusan Teknik Geomatika, FTSP Institut Teknologi Sepuluh Nopember \\ e-mail: sayyidatulkhoiridah@gmail.com
}

\begin{abstract}
Abstrak. Telah dilakukan penelitian tentang estimasi durasi rupture pada gempa bumi Nias, 28 Maret 2005 dengan tujuan untuk mengetahui karakteristik dari gempa bumi pembangkit tsunami. Lokasi Nias dipilih pada penelitian ini karena dampak yang diakibatkan oleh gempa bumi Nias sangat dan dapat berpotensi terjadi tsunami. Data yang digunakan adalah wave form dengan komponen vertikal yang memiliki coverage yang baik dan noise-nya kecil. Hasil dari estimasi durasi rupture pada gempa Nias di masing-masing stasiun yaitu FURI 129,28 detik, KMI 51,93 detik, WRAB 90,25 detik, DGAR 151,15 detik, dan GUMO 105,30 detik. Hasil estimasi durasi rupture tersebut berpotensi kuat terjadi tsunami karena lebih dari 50 detik.
\end{abstract}

Kata Kunci: durasi rupture; Nias; tsunami

\begin{abstract}
Has done research on the estimated rupture duration of the earth quake in Nias, March 28, 2005 with the purpose to determine the characteristics of the tsunamigenic earth quake. Nias area chosen in this study because of the impact caused by the earth quake Nias greatly and can potentially tsunami. The data used is a wave form with a vertical component that has good coverage and small noise. Results of the estimated rupture duration in the Nias earth quake a teach station that is FURI 129,28 seconds, KMI 51,93 seconds, WRAB 90,25 seconds, DGAR 151,15 seconds, and Gumo105,30 seconds. The rupture duration estimation results potentially powerful tsunamis because more than 50 seconds.
\end{abstract}

Keywords: rupture duration; Nias; tsunami

\section{PENDAHULUAN}

Indonesia berada pada pertemuan antara tiga lempeng besar yaitu India-Australia, Pasifik, dan Eurasia. Lempeng Eurasia relatif diam, sementara lempeng Pasifik bergerak ke arah Timur menekan lempeng Eurasia dan lempeng Indo-Australia bergerak ke arah Utara menekan lempeng Eurasia. Kejadian gempa bumi besar dan merusak umumnya terjadi di sepanjang pertemuan ketiga lempeng besar tersebut dan juga pada jalur patahan-patahan aktif yang terbentuk di bagian interior lempeng kepulauan Indonesia. Sebagian sumber gempa bumi tesebut berada di bawah laut sehingga berpotensi tsunami (Natawidjaya, 2007).

Tsunami dapat dibangkitkan oleh gempa bumi yang terjadi di dasar laut. Tsunami jenis ini sering terjadi. Tsunami juga bisa disebabkan oleh letusan gunung api di bawah laut (tidak sering terjadi), tanah longsor di dasar laut (jarang terjadi), dan yang dapat meghancurkan dan menghanyutkan bangunan-bangunan di tepi pantai. Dengan jatuhnya komet/meteorit besar di laut (belum pernah terjadi) (Rais, 2006).

Tsunami dapat dihasilkan ketika tiba-tiba terjadi deformasi di dasar laut dan pergeseran vertikal dari air yang berada di atasnya (Gambar 1). Seluruh kolom air terganggu oleh pengangkatan atau penurunan dasar laut. Gelombang air terbentuk sebagai upaya massa air yang dipindahkan kembali ke posisi keseimbangannya. Gelombang ini mempengaruhi seluruh kolom air di antara permukaan dan dasar laut ketika bergerak dari daerah asal di tengah laut menuju pantai (Meijde, 2005).

Energi elastik yang tersimpan di dalam bumi dilepaskan ketika terjadi gempa bumi dan selanjutnya energi ini ditransfer menjadi gelombang tsunami. Gelombang tsunami yang dipicu oleh gempa bumi merupakan bahaya ikutan demikian, setelah terjadi gempa bumi kemudian apakah gempa bumi tersebut dapat memicu 
terjadinya tsunami atau tidak sangat bergantung pada besar energi. Rupture gempa bumi dipengaruhi oleh energi yang dilepaskan oleh sumber gempa bumi tersebut. Dalam teori seismologi, energi yang dilepaskan oleh sumber gempa bumi diilustrasikan sebagai momen seismik $\left(M_{0}\right)$ yang mengakibatkan terbentuknya luas dan slip dari rupture sebagaimana dinyatakan pada persamaan 2.28 (Madlazim, 2011).

Telah ditemukan oleh Lomax dan Michelini (2009; 2011) bahwa parameter panjang rupture (L) merupakan parameter yang paling dominan pengaruhnya terhadap terjadinya tsunami. Lomax dan Michelini (2009; 2011) juga menemukan hubungan antara $L$ dan durasi rupture sebanding dengan panjang rupture. Untuk mengukur panjang rupture diperlukan metode yang komplek dan membutuhkan waktu komputasi yang lebih lama, sehingga tidak layak digunakan untuk peringatan dini tsunami. Sedangkan untuk mengestimasi durasi rupture bisa dilakukan dengan cara menganalisis seismogram-seismogram grup gelombang $\mathrm{P}$ yang dominan dari seismogram frekuensi tinggi dari gempa bumi (Madlazim, 2011).

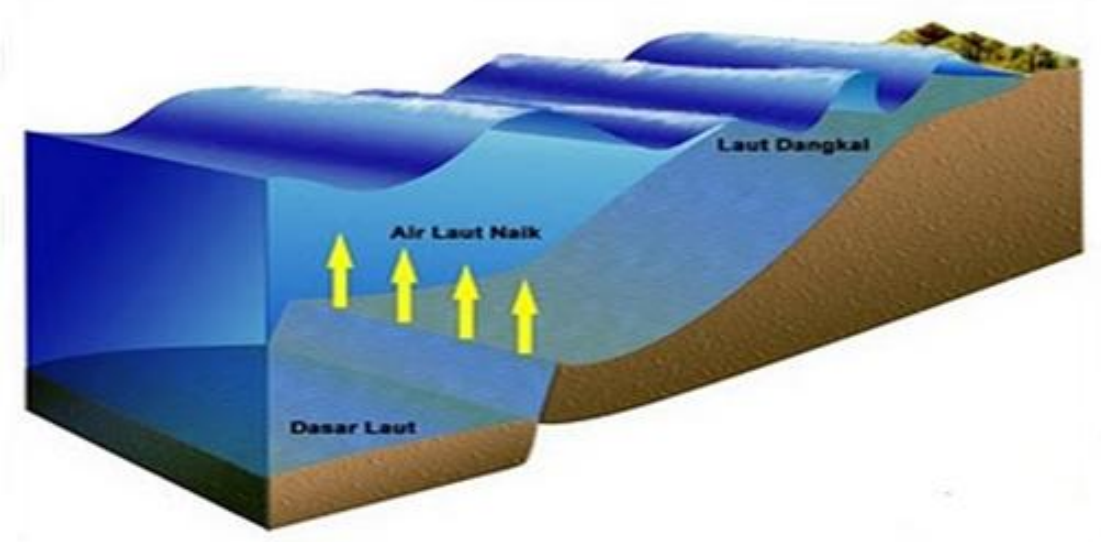

Gambar 1. Mekanisme Tsunami yang Dipicu oleh Gempa Bumi (Rais).

Gelombang seismik $\mathrm{P}$ adalah sinyal pertama dari suatu gempa bumi yang diterima oleh stasiun perekam. Pengalaman telah menunjukkan bahwa seismogram frekuensi tinggi (periode $<1$ s) mengandung sinyal-sinyal utama dari gelombang $P$ yang dipancarkan secara langsung dari rupture dengan sedikit interferensi dari gelombang yang terpantul pada permukaan bumi yang disebut fase SP. Dengan demikian, dalam rekaman gelombang $P$ frekuensi tinggi terdapat sekitar setelah 20 menit setelah even yang memberikan informasi tentang awal sampai akhir dari proses rupture (Lomax and Michelini, 2005). Dengan asumsi bahwa kecepatan rupture suatu gempa bumi besar adalah konstan sepanjang permukaan sesar. Asumsi ini memberi konsekuensi untuk gempa bumi besar kecepatan, rata-rata slip, dan lebar rupture sama untuk semua

$$
T_{d u r}=\frac{L}{z^{q}}
$$

even sehingga hanya panjang rupture saja yang memberi pengaruh yang paling dominan terhadap proses rupture. Panjang rupture ini berhubungan secara langsung dengan parameter durasi rupture dari gelombang $\mathrm{P}$ utama $\left(\mathrm{T}_{\text {dur }}\right)$. Hubungan ini dapat dinyatakan sebagai sebagaimana pada persamaan (1).

$$
T_{d u r}=\frac{L}{v_{r}}
$$

dengan $v_{r}$ adalah kecepatan rupture yang sebanding dengan kecepatan gelombang $\mathrm{S}$.

Sedangkan dalam seismologi, telah diketahui bahwa $v_{r}$ sebanding dengan $z^{q}$ ( $z$ : kedalaman dan $q$ : koefisien yang bernilai positif), sehingga hubungan $L$ dan $z$ bisa dinyatakan sebagai berikut: 
Persamaan ini memberi ilustrasi bahwa semakin besar $\mathrm{T}_{\text {dur, }}$ maka semakin besar $L$ dan semakin kecil z. Dua kondisi ini merupakan karakteristik dari keriteria untuk terjadinya potensi tsunami (Lomax and Michelini, 2011).

Untuk menghitung $T_{d u r}$ dapat ditentukan dari waktu delay setelah kedatangan gelombang $\mathrm{P}$ untuk 90\% $\left(T^{0,9}\right), 80 \%\left(T^{0,8}\right), 50 \%\left(T^{0,5}\right)$, dan $20 \%$ $\left(\mathrm{T}^{0,2}\right)$ dari nilai puncaknya. Adapun persamaan matematis untuk menghitung $T_{\text {dur }}$ dapat ditentukan sebagai berikut:

$$
\begin{aligned}
& T_{d u r}=(1-w) T^{0,9}+w T^{0,2} \\
& w=\left[\left(T^{0,2}+T^{0,5}\right) / 2-20\right] / 40 s
\end{aligned}
$$

dengan batasan T0,9 $<\mathrm{T}_{d u r}<\mathrm{T} 0,2$. Dimana untuk gempa lokal menggunakan HF filtered bandpas antara $1-5 \mathrm{~Hz}$. Sedangkan untuk gempa teleseismik menggunakan $\mathrm{HF}$ filtered $5-20 \mathrm{~Hz}$ (Madlazim, 2011).

Zona subduksi Sumatra merupakan jalur gempa bumi di Indonesia yang paling banyak menyerap dan mengeluarkan energi gempa bumi dengan magnitudo relatif besar $(\mathrm{Mw} \geq 8)$ sehingga dapat berpotensi terjadi tsunami (Natawidjaja, 2002; Newcomb and McCann, 1987). Salah satu segmen yang berada persis di atas zona megathrust (sumber gempa zona subduksi) dan pernah terjadi gempa bumi sampai membangkitkan tsunami adalah Nias (Natawidjaja, 2007). Lihat Gambar 2.

Gempa bumi Nias yang sampai mengakibatkan tsunami terjadi pada tanggal 28 Maret 2005 dengan magnitudo $M_{W}$ 8,7. Gempa tersebut merupakan gempa bumi terbesar kedua setelah gempa bumi Aceh-Andaman yang terjadi pada tanggal 26 Desember 2004 dengan magnitudo Mw 9,0 (Briggs et al., 2006; Rooke, 2008).

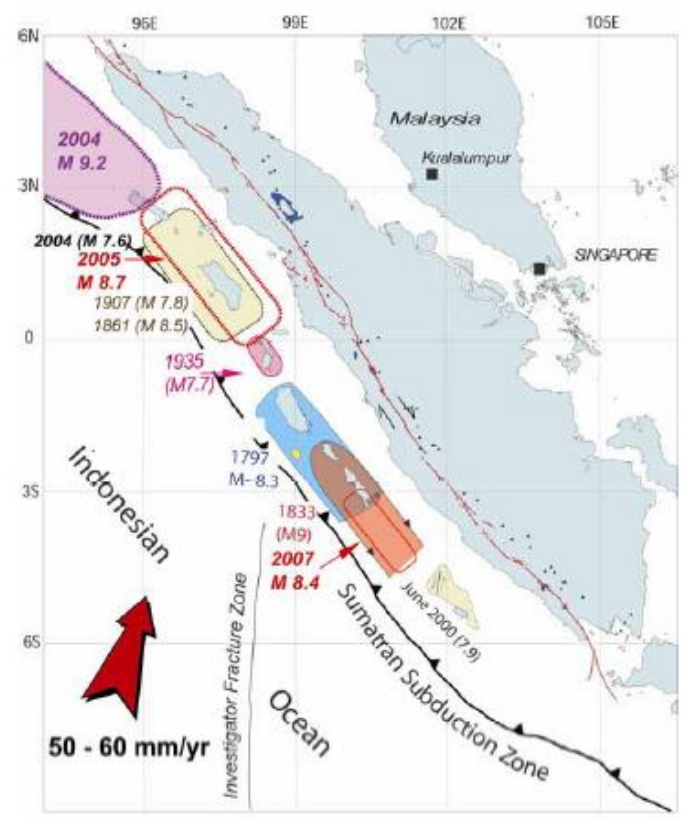

Gambar 2. Tektonik Aktif Pulau Sumatra yang Mempengaruhi Gempa Bumi Nias (Natawidjaja, 2007).

Gempa Nias 2005 telah memakan korban jiwa hampir dua ribu orang dan menghancurkan banyak bangunan di sekitar kota Gunung Sitoli dan Sinabang, daerah dengan populasi terpadat. Selain itu, gempa Nias juga mengakibatkan terjadinya proses pengangkatan dan penurunan muka bumi antara 1 - 3 meter yang memberikan dampak kerusakan pada lingkungan. Pengangkatan muka bumi terjadi di sepanjang tepian pantai Barat Nias dan di bagian Selatan Simelue. Sedangkan penurunan terjadi di bagian Barat, wilayah Timur Simelue, Banyak dan Nias (Natawidjaja, 2007).

Studi kasus yang dipilih pada penelitian ini adalah gempa bumi Nias yang terjadi pada tanggal 28 Maret 2005. Hal itu dikarenakan melihat dampak yang diakibatkan oleh gempa Nias sangat besar. Selain itu, gempa Nias 2005 berada di wilayah lautan dan di zona subduksi sehingga dapat mengakibatkan terjadinya tsunami, terlebih di zonazona subduksi Sumatera telah terjadi ratusan gempa bumi dan tentu saja akan tetap terjadi gempa bumi dengan kekuatan besar maupun kecil di masa-masa mendatang. Di segmen Nias dalam kurun 200 tahun terakhir ini sudah mengalami 4 kali 
bencana gempa bumi dan tsunami, yaitu tahun 1861 (M 8,5), 1907 (M 7,4), 2004 (M 9,2), dan 2005 (M 8,7). Gempa bumi terakhir yang memecahkan segmen (sumber gempa) yang sama dengan gempa 2005 adalah gempa bumi tahun 1861. Dengan kata lain, segmen Nias terakhir melepaskan simpanan energinya sekitar 145 tahun yang lalu (Natawijaya, 2007).

Dinamika tektonik sebagai kejadian alam tidak dapat dicegah, namun pemahaman gejala sangat diperlukan untuk mengurangi korban bencana gempa bumi dan tsunami tersebut. Salah satu upaya yang dapat dilakukan adalah perencanaan dan pemanfaatan sistem mitigasi bencana gempa bumi dan tsunami yang memiliki kinerja yang baik. Dalam upaya tersebut, pemahaman mekanisme sumber gempa dan tsunami memerlukan data durasi rupture yang akurat (Lomax and Michelini, 2009; 2011). Oleh karena itu, pada penelitian ini akan dilakukan estimasi durasi rupture pada gempa bumi pembangkit tsunami (tsunamigenic earthquake) yang terjadi di segmen Nias pada 28 Maret 2005 untuk mengetahui karakteristik dari gempa tersebut.

\section{METODOLOGI}

Penelitian ini menggunakan data gempa bumi Nias 28 Maret 2005 yang diambil dari instansi IRIS (Incorporated Reasearch Institutions for Seismology). Koordinat gempa berada pada 2,0964 ${ }^{\circ} \mathrm{LU}$ dan 97,1131 ${ }^{\circ} \mathrm{BT}$ dengan waktu kedatangannya yaitu 16:09:35 UTC. Gempa berada pada kedalaman $30 \mathrm{~km}$ dan magnitudonya Mw8,1 SR. Gempa yang digunakan termasuk gempa teleseismik dengan stasiun yang digunakan dapat dilihat pada Tabel 2.

Algoritma yang digunakan untuk mengestimasi durasi rupture adalah:

(1) menyediakan seismogram komponen vertikal dalam format SAC sebagai raw data (Goldstein and Snoke, 2005);

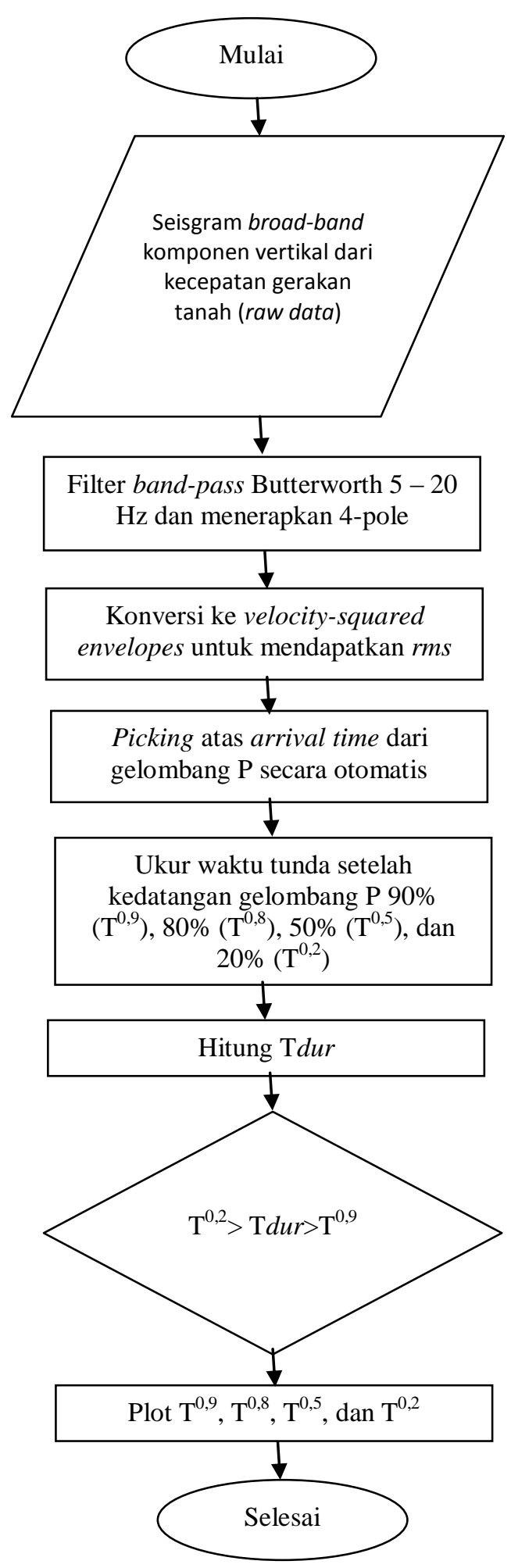

Gambar 3. Diagram Alir Estimasi Durasi Rupture. 
(2) menerapkan 4-pole dan filter band-pass Butterworth $5-20 \mathrm{~Hz}$ untuk mendapatkan seismogram rekaman kecepatan pada high frequency (HF) untuk masing-masing stasiun;

(3) mengkonversi seismogram HF tersebut menjadi velocity-squared envelopes untuk mendapatkan $r m s$ amplitudo;

(4) melakukan picking atas arrival time dari gelombang $P$ secara otomatis pada seismogram HF tersebut;
(5) mengukur delay waktu setelah kedatangan gelombang $\mathrm{P}$ untuk $90 \%\left(\mathrm{~T}^{0,9}\right), 80 \%\left(\mathrm{~T}^{0,8}\right), 50 \%$ $\left(T^{0,5}\right)$, dan $20 \%\left(T^{0,2}\right)$ dari nilai puncaknya;

(6) menghitung durasi rupture untuk masingmasing stasiun yang digunakan dengan menggunakan persamaan (3) dan (4) dan nilai $w$ dibatasi $0 \leq w \leq 1$ (Lomax and Michelini, 2009);

(7) Plot $T^{0,2}, T^{0,5}, T^{0,8}, T^{0,9}$, dan $T_{\text {dur }}$ pada seismogram. Algoritma tersebut diimplementasikan ke dalam software SeisGram2k untuk menghitung $\mathrm{T}_{\text {dur. }}$. Adapun diagram alir metode estimasi durasi rupture dapat dilihat pada Gambar 3.

Tabel 1. Data Gempa Bumi Nias 28 Maret 2005 dan Mentawai 25 Oktober 2010 (Sumber IRIS).

\begin{tabular}{cccccc}
\hline Event & Latitude & Longitude & Origine Time & Kedalaman & Magnitude \\
\hline Nias & $2,0964^{\circ}$ & $97,1131^{\circ}$ & $16: 09: 35$ UTC & $30 \mathrm{Km}$ & $8,1 \mathrm{SR}$ \\
\hline
\end{tabular}

Tabel 2. Stasiun Gempa Bumi Nias, 28 Maret 2005

\begin{tabular}{ccccc}
\hline Nama Stasiun & Latitude (deg) & Longitude (deg) & Distance (deg) & Elevasi (m) \\
\hline FURI & 8,90 & 38,68 & 58,50 & 2570 \\
KMI & 25,12 & 102,74 & 23,66 & 1975 \\
WRAB & $-19,93$ & 134,36 & 42,66 & 366 \\
DGAR & $-7,41$ & 72,45 & 26,38 & 1 \\
GUMO & 13,59 & 144,87 & 48,58 & 170 \\
\hline
\end{tabular}

\section{HASIL DAN PEMBAHASAN}

Tabel 3 merupakan hasil estimasi durasi rupture pada gempa bumi Nias 28 Maret 2005 yang menunjukkan bahwa potensi tsunami tidak hanya bergantung pada besar magnitude dan kedalaman dari sumber gempa. Durasi rupture memiliki pengaruh besar untuk memicu terjadinya tsunami. Berdasarkan hasil penelitian yang dilakukan oleh Okal (1988), Geist and Yoshika (1996), dan Lomax and Michelini (2011) menjelaskan bahwa gempa bumi yang memiliki durasi rupture lebih dari 50 detik dapat memicu terjadinya tsunami. Hal tersebut memiliki kesesuaian dengan hasil estimasi pada penelitian ini, dimana estimasi durasi rupture gempa bumi Nias 2005 yang terekam pada masingmasing stasiun gempa memiliki nilai lebih dari 50 sekon dan dalam kenyataannya telah menimbulkan terjadinya tsunami.

Durai rupture sebanding dengan panjang rupture, sehingga semakin lama durasi rupture suatu gempa, maka semakin besar pula panjang rupturenya (Lomax dan Michelini (2005). Semakin 
panjang rupture suatu gempa bumi, semakin besar peluang gempa bumi tersebut memicu tsunami, bila gempa tersebut terjadi di laut. Hal ini berarti bahwa parameter sumber gempa bumi yang dapat digunakan sebagai peringatan dini tsunami secara cepat dan lebih akurat adalah durasi rupture gempa bumi. Gempa bumi yang memiliki tipe sesar strike slip pun bisa menimbulkan tsunami, bila rata-rata nilai durasi rupture gempa bumi lebih dari ambang batas (50 detik).

Tabel 3. Hasil Estimasi Durasi Rupture pada Gempa Bumi Nias, 28 Maret 2005.

\begin{tabular}{cccccc}
\hline Nama Stasiun & T0,9 (s) & T0,8 (s) & T0,5 (s) & T0,2 (s) & Tdur (s) \\
\hline FURI & 62,30 & 63,10 & 65,35 & 135,85 & 129,28 \\
KMI & 35,15 & 36,00 & 46,65 & 88,80 & 51,93 \\
WRAB & 64,90 & 66,25 & 85,15 & 95,30 & 90,25 \\
DGAR & 72,85 & 73,55 & 113,95 & 156,20 & 151,15 \\
GUMO & 61,25 & 62,15 & 70,25 & 110,35 & 105,30 \\
\hline
\end{tabular}

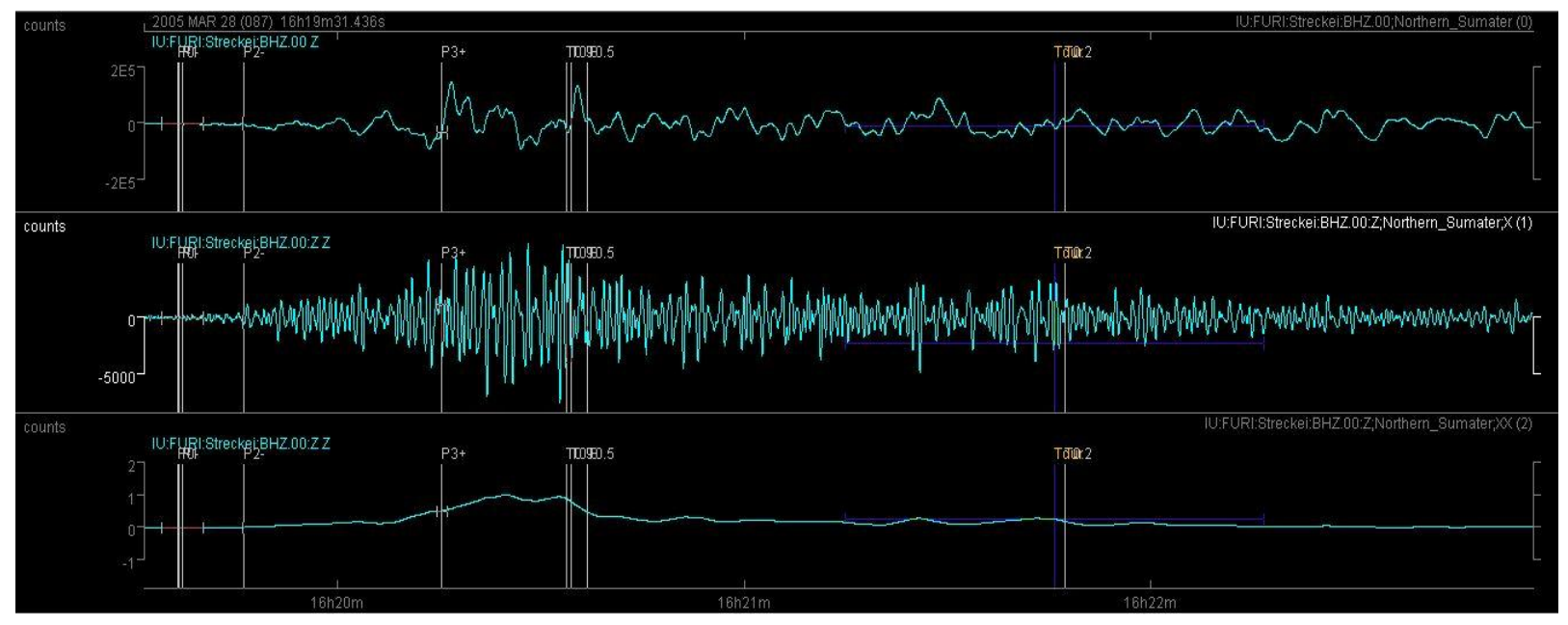

Gambar 4.Hasil Estimasi Durasi Rupture Gempa Nias 2005 pada Stasiun FURI (Tdur= 129,28 s).

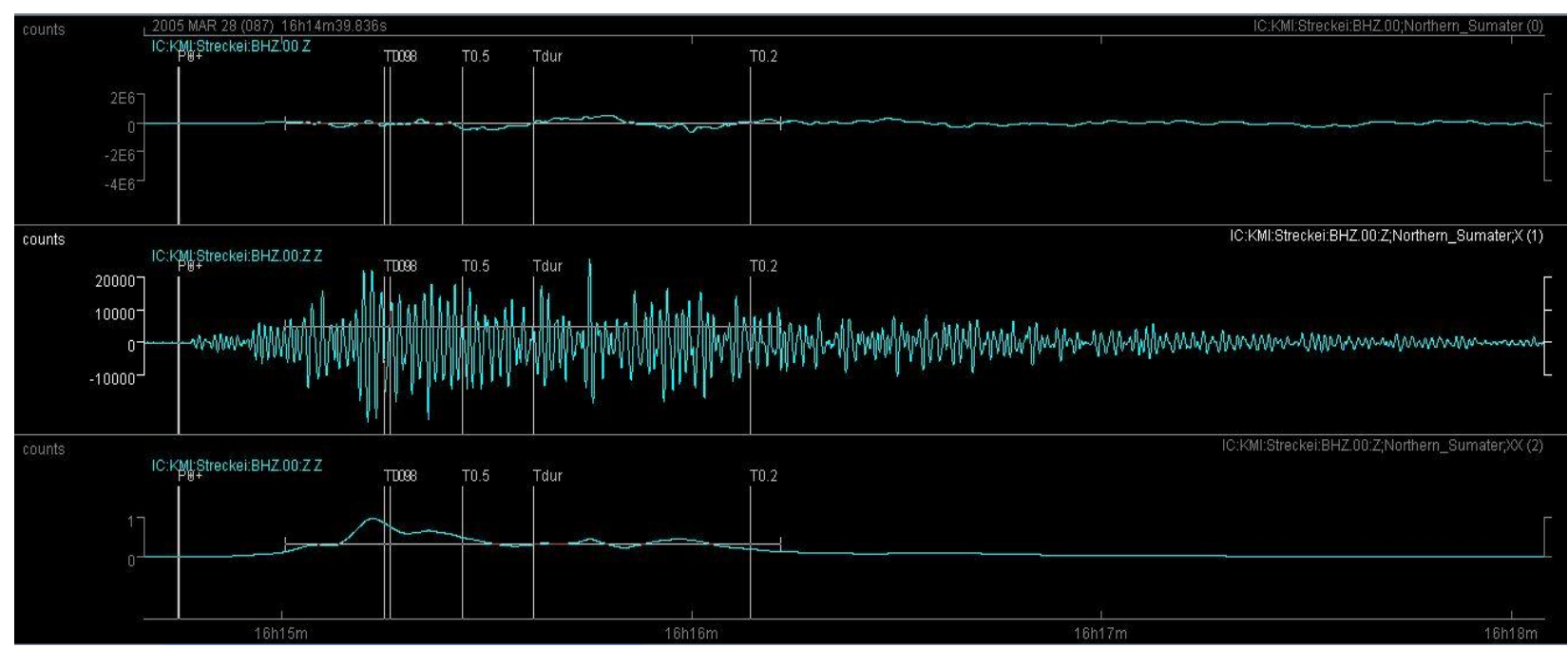

Gambar 5.Hasil Estimasi Durasi Rupture Gempa Nias 2005 pada Stasiun KMI (Tdur = 51,93 s) 


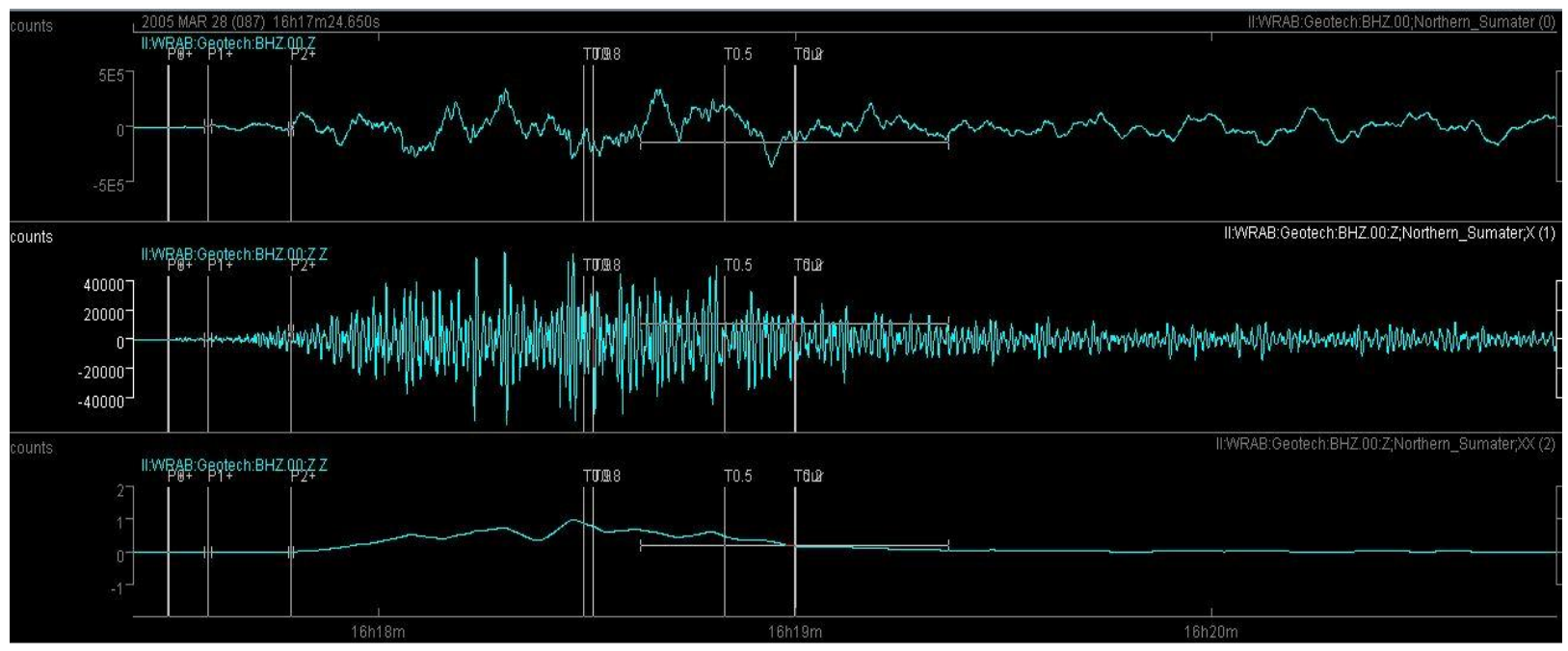

Gambar 6.Hasil Estimasi Durasi Rupture Gempa Nias 2005 pada Stasiun WRAB (Tdur = 90,25 s)

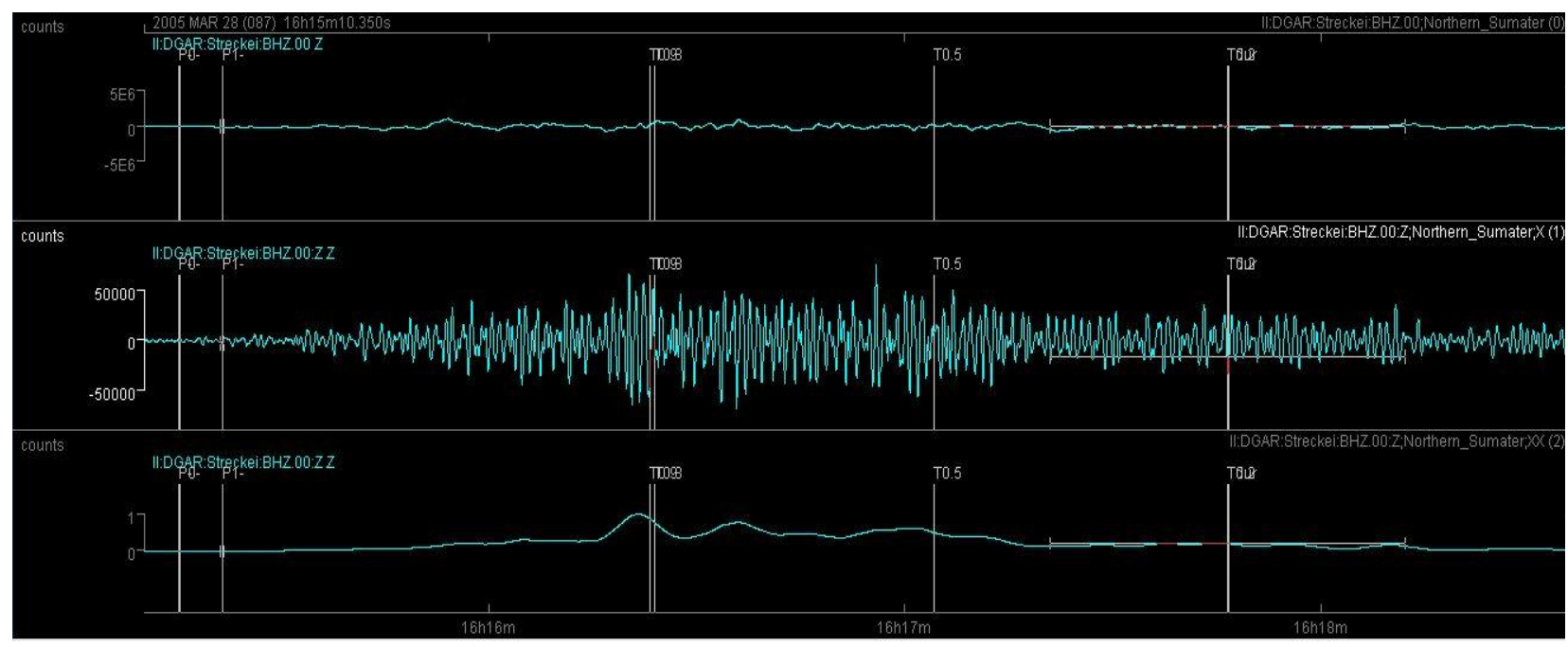

Gambar 7.Hasil Estimasi Durasi Rupture Gempa Nias 2005 pada Stasiun DGAR (Tdur = 151,15 s)

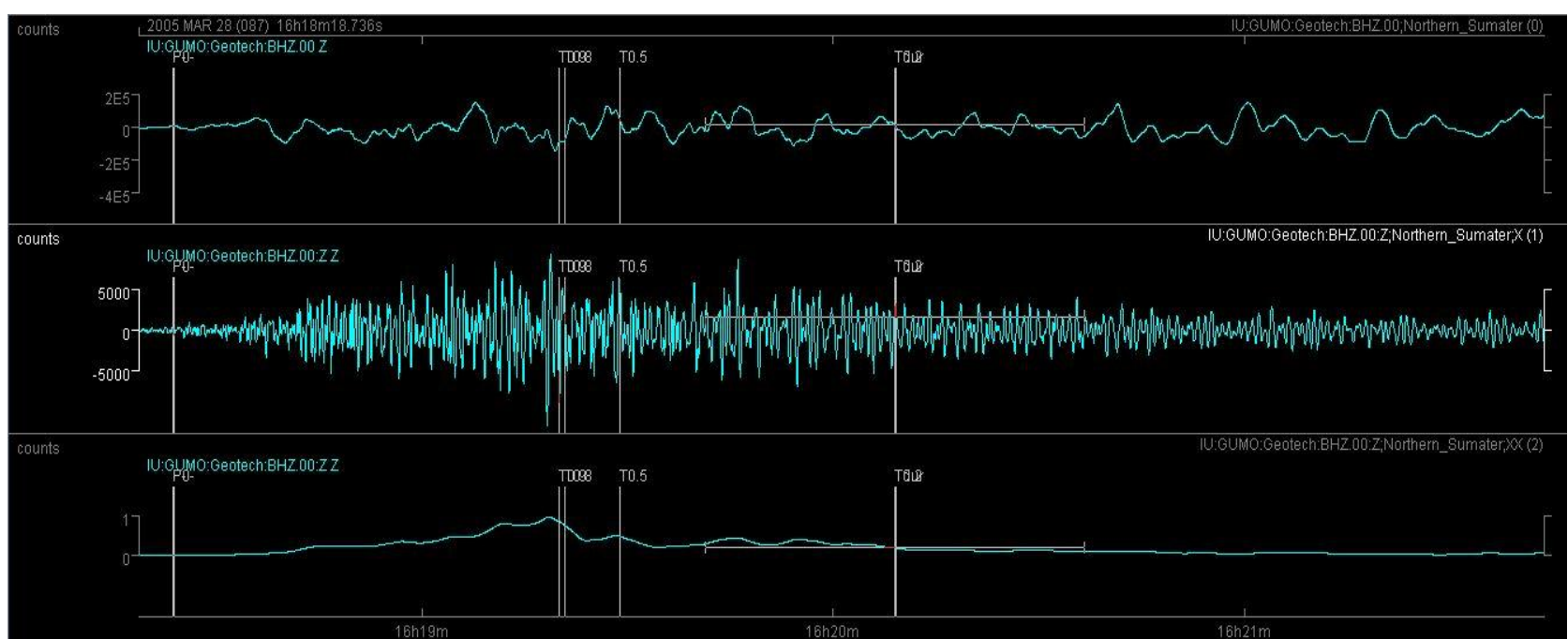

Gambar 8. Hasil estimasi durasi rupture gempa Nias 2005 pada stasiun GUMO (Tdur = 105,30 s) 


\section{KESIMPULAN}

Hasil estimasi durasi rupture pada gempa Nias di masing-masing stasiun yaitu FURI 129,28 detik, KMI 51,93 detik, WRAB 90,25 detik, DGAR 151,15 detik, dan GUMO 105,30 detik. Hasil estimasi durasi rupture tersebut berpotensi kuat terjadi tsunami karena lebih dari 50 detik. Penerapan durasi rupture sebagai indikator potensi tsunami lebih akurat dibandingkan dengan magnitudo, kedalaman, dan tipe sesar.

\section{DAFTAR PUSTAKA}

Briggs, R.W., K. Sieh, A.J. Meltzner, D.H. Natawidjaja, dkk., 2006. Deformation and Slip Along The Sunda Megathrust in The Great 2005 Nias-Simeulue Earthquake. Science, 311 (5769), 1897-1901.

Geist, E. and Yoshioka, S., 1996. Source Parameters Controlling the Generation and Propagation of Potential Local Tsunami, Natural Hazards 13: 151177.

Lomax, A., and Michelini A., $2005 . \quad$ Rapid Determination of Earthquake Size for Hazard Warning, EOS, Trans. Am. Geophys. Un., 86 (21): 202.

Lomax, A. and Michelini A., 2009. Mwpd: A DurationAmplitude Procedure for Rapid Determination of Earthquake Magnitude and Tsunamigenic Potential from P Waveform. Geophysics.J.Int.,176:200214,doi:10.1111/j. 1365-246X.2008.

Lomax, A. and Michelini, A., 2011. Tsunami Early Warning using Earthquake Rupture Duration and PWave Dominant Period: The Importance of Length and Depth of Faulting. Geophys. J. Int., 185: 283291. Doi: 10.1111/j.136 246X.2010.

Madlazim., 2011. Estimasi CMT, Bidang Sesar dan Durasi Rupture Gempa Bumi Di Sumatera Serta Kemungkinan Penerapannya Untuk Sistem Peringatan Dini Tsunami. Institute Teknologi Sepuluh Nopember Surabaya (disertasi).

Meijde, M. V. D., 2005. Earthquake as Driving Mechanism Behind Tsunamis, International Institute for Geo Information Science and Earth Observation, (www.itc.nl/library/Paper_ 2005/tsunami/Earthquake.pdf).

Natawidjaya, D.H., 2002. Neotectonics of the Sumatera Fault and Paleogeodesy of the Sumatera Sudbuction Zone. California Institute of Technology Pasadena. California (Thesis).
Natawidjaya, D.H., 2007. Gempa Bumi dan Tsunami di Sumatera dan Upaya untuk Mengembangkan Lingkungan Hidup yang Aman dari Bencana Alam. Vol. 136.

Newcomb, K.R., and W. R. McCann., 1987. Seismic History and Seismotectonics of the Sunda Arc. Journal of Geophysical Research, 92: 421-439.

Okal, E. A., 1988. Seismic Paramters Controlling Farfield Tsunami Amplitudes: a Review, Nat. Hazard, 1: 67-96.

Rais, J., 2006. Indonesia di Antara Dua Samudera, Dua Benua, dan Tiga Lempeng Tektonik Mega, ITB, Bandung.

Rooke, N. Chamot., 2008. Stress Chage and Effective Friction Coefficient along the Sumatera-AndamanSagaing fault system after the 26 December 2004 $(M w=9,2)$ and the28 March $2005(M w=8.7)$ Eartquakes. Paris : AGU and Geochemical Society. 